\title{
Characterization of caves as bat roosts in the brazilian-paranense biogeographic region of Bolivia
}

\author{
Dennis Lizarro ${ }^{1,2}$, luis F. Aguirre ${ }^{2,3 *}$, José Carlos Pérez-Zubieta ${ }^{2,3}$, Aideé Vargas ${ }^{2,4}$, and M. Isabel Galarza ${ }^{2}$ \\ ${ }^{1}$ Centro de Investigación de Recursos Acuáticos, Universidad Autónoma del Beni "José Ballivián" (CIRA-UABJB). Campus “Dr. \\ Hernán Melgar Justiniano", Trinidad. Beni, Bolivia. Email: delizarroz@uabjb.edu.bo (DL). \\ 2 Fundación PCMB, Programa para la Conservación de los Murciélagos de Bolivia. Cochabamba y Beni, Bolivia. Email: \\ isabelgalarza3000@gmail.com (MIG). \\ ${ }^{3}$ Centro de Biodiversidad y Genética, Universidad Mayor de San Simón, Casilla 538, Cochabamba, Bolivia. Email: laguirre@fcyt. \\ umss.edu.bo (LFA), perezzubieta@gmail.com (JCP-Z). \\ ${ }^{4}$ Fundación Natura Bolivia, Santa Cruz, Bolivia. Email: chiroderma@gmail.com (AV). \\ ${ }^{*}$ Corresponding author
}

Bats play vital roles in nature as pollinators, seed dispersers, and natural controllers of insect pests. They serve as indicators of habitat disturbance and provide an insight into the health status of an ecosystem. This enormous importance contrasts with the lack of information on the current state of their roosts in Bolivia, particularly as regards caves and caverns. A search for caves and caverns was carried out in the eastern department of Santa Cruz, Bolivia, corresponding to the Brazilian-Paranense biogeographic region. Subsequently, an environmental-structural characterization of the caves was conducted to obtain biological information by capturing and identifying bats in eastern Bolivia. Interspecific associations in caves and the relationship between roost characteristics and bat diversity were explored and described based on the variables evaluated. A total of 19 caves were evaluated. A correlation between environmental and structural parameters was investigated, showing a relationship between cave length and humidity. Seven species of cave bats were identified, and two species of threatened Bolivian bats (Lonchorhina aurita and Natalus macrourus) were found in four caves. The caves evaluated are new records of this vital habitat for bats in the country. The presence or absence of bat species was found to depend on the structural characteristics of the cave (length, complexity), but not on temperature, although humidity may play a role in the presence of species. Among the species found, those highly specialized in the selection and use of roosts at caves could be prone to local extinctions. It is suggested that further investigations should be carried out on the ecology of these cave-dwelling bat species to identify the roosting patterns of bats and their distribution range, to elaborate conservation and management programs for caves and the animal communities sheltered.

Los murciélagos cumplen roles muy importantes en la naturaleza como polinizadores, dispersores de semillas, controladores naturales de plagas de insectos, son indicadores de niveles de perturbación de hábitats y ofrecen una amplia visión de la salud de un ecosistema. Esta enorme importancia contrasta con la falta de información sobre el estado actual de sus refugios en Bolivia, particularmente aquella relacionada con cuevas y cavernas. Se realizó una búsqueda de cuevas y cavernas en el este del departamento de Santa Cruz, Bolivia, correspondiente a la región biogeográfica Brasileño-Paranense. Posteriormente, se registraron las características ambientales-estructurales de las cuevas y se obtuvo información biológica mediante captura e identificación de murciélagos en el este de Bolivia. Se determinó la asociación interespecífica en las cuevas y la relación existente entre las características de los refugios con la diversidad de murciélagos con la finalidad de describir estos refugios en función a sus variables evaluadas. Un total de 19 cuevas fueron evaluadas. Los parámetros ambientales se correlacionaron con los estructurales mostrando relación entre la longitud y la humedad. Se identificaron siete especies de murciélagos cavernícolas, resaltando que en cuatro cuevas se encontraron dos especies de murciélagos amenazados (Lonchorhina aurita y Natalus macrourus) en Bolivia. Las cuevas evaluadas son nuevos registros para el país de este importante componente del hábitat. Se determinó que la presencia o ausencia de especies de murciélagos se correlaciona con las características estructurales del refugio (largo, complejidad) y no de sus valores de temperatura, aunque la humedad podría ser una causa próxima para la presencia de las especies. Se encontraron especies de alta especialización en el uso de cuevas que podrían ser susceptibles a extinciones locales. Se sugiere realizar más investigaciones sobre la ecología de estas especies de murciélagos que habitan en cuevas, a fin de identificar los patrones de refugio de murciélagos, su rango de distribución y generar programas de conservación y gestión para las cuevas y su fauna.

Keywords: caves; bats; conservation; roosts.

(C) 2020 Asociación Mexicana de Mastozoología, www.mastozoologiamexicana.org

\section{Introduction}

Mammal recording in Bolivia has been conducted over a long time (Tarifa 2014), with the work of Sydney Anderson as a cornerstone for contemporary mammalogy in the country. Sydney Anderson conducted studies from 1964 to 1993; his efforts, which spanned over nearly three decades, resulted in a reference book for Bolivian mammalogy (Anderson 1997). In subsequent decades, the study of mammals has increased significantly, as regards not only taxonomic aspects (Aguirre et al. 2019) but also investigating ecological (Wallace et al. 2010) and conservation features (Tarifa and Aguirre 2009). Anderson was also the first to set the grounds for the study of bats in Bolivia, publishing a preliminary list of 79 species (Anderson et al. 1982). This information provided the basis for multiple publications on bats, including compilations of the current state of knowledge (Aguirre 2007) and taxonomic revisions (e. g., Siles et al. 2013), up to complex 
ecological studies (e. g., Aguirre et al. 2016; Siles et al. 2007). From the work of Anderson et al. (1982), the richness of bat species known to Bolivia has increased significantly to 138 species currently reported (Aguirre et al. 2019), equivalent to approximately two records of new species per year over a decade (Aguirre et al. 2009).

Bats, which account for some $50 \%$ of the mammalian fauna of tropical rainforests (Patterson et al. 2003), play a central role as pollinators, seed dispersers, and natural pest controls in crops (Cleveland et al. 2006; Bracamonte 2011; Kunz et al. 2011). Also, they have a huge potential as indicators of habitat disturbance levels (Kunz et al. 2011; Castro-Luna et al. 2007; Park 2015) and provide a broad view of the health of ecosystems, as they exploit different trophic resources in Neotropical forests (García-Morales et al. 2013). This considerable importance contrasts with the lack of information on the current status of their roosts (Kunz 1982; Arita and Vargas 1995; Aguirre 2007; Siles et al. 2007) and the misconception or erroneous beliefs about them, leading to ungrounded extermination of individuals or colonies (Hutson et al. 2001; Lizarro et al. 2010).

Bats need roosts to shelter from adverse weather conditions and predators (Kunz and Fenton 2003), where breeding, nursing, or temporary roosting colonies are also established between migrations (Altringham 2011). Therefore, roost characteristics and roost-related processes play a central role in the ecology and evolution of different bat species (Kunz 1982).

There is little knowledge in Bolivia about the availability of roosts for bats, given the few studies carried out on this topic. Of the 138 bat species registered (Aguirre et al. 2019), at least 35 use caves as primary or alternative roosts (Aguirre 2007; Moya et al. 2007; Siles et al. 2007) and at least 12 can be considered as strict cave dwellers (Aguirre 2007). Bat species inhabiting these roosts may be listed under a threatened category, mainly because of the specificity of the sites uses and for having small populations, which is aggravated by the destruction or misuse of caves, indiscriminate killing, and because of negative misbeliefs and myths (Galarza and Aguirre 2007). Knowing and protecting the natural roosts of bats, especially those of threatened species, are essential for the conservation of key elements of biodiversity (Aguirre et al. 2010). This study aims to contribute basic information on the characteristics of cave roosts that are regularly or occasionally inhabited by bats, as well as on the use of caves (position, resting sites, and interactions), in the east of the department of Santa Cruz, Bolivia. With the data obtained, we expect to set biological bases for the implementation of conservation strategies that ensure the survival of bat populations.

\section{Materials and Methods}

Study Area. We carried out a comprehensive search of caves and caverns in the east of the department of Santa Cruz, Bolivia, corresponding to the Brazilian-Paranense biogeographic region (Navarro 2011), starting with a literature review and gathering incidental information from local inhabitants. Each of the caves was located and georeferenced in the localities (Figure 1). The localities where caves and caverns with the presence of bat species were recorded are Huanchaca Plateau, San Matías, Santiago de Chiquitos, Puerto Suárez, Roboré, Ascension de la Frontera, and San Ignacio de Velasco (Figure 1).

Characterization of caves. The fieldwork was conducted from June 2008 to March 2009, with a three-day visit to each cave. The environmental-structural characteristics of each cave were recorded using a methodology adapted from Siles et al. (2007). We measured the distance at both sides (width) and to the roof (height) at one-meter intervals and recorded the temperature and humidity during the same period of time in each cave (9:00 to 14:00 hrs). Since the environmental variables measured may be biased by seasonal variations, the results include the month when each cave was evaluated (Table 1), in the understanding that the data obtained characterize each cave at a particular time point. In addition, notes were made regarding the illumination in sites where individuals were recorded or the distance from the entrance to the cave.

The particular location of species within caves during the day, resting sites, and interspecific interactions were recorded on days when neither measurements were taken nor bats were captured, for a similar period of time for each cave. The size of each colony was estimated according to the number of bats observed during daytime visits: for small colonies $(<30$ individuals/colony), all individuals could be counted directly; for larger colonies, photographs were taken and individuals were counted on the printout. No attempt was made to estimate absolute population sizes from catch data; instead, this information was used for validating species identification and estimating relative abundance.

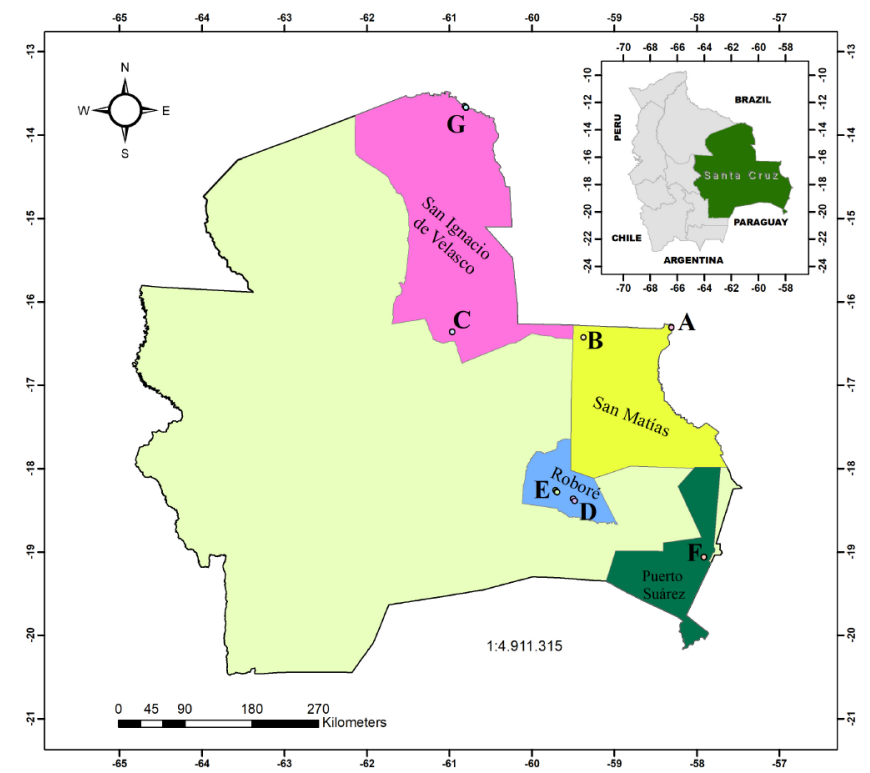

Figure 1. Location map of the 7 study sites where the 19 caves were located in the department of Santa Cruz, Bolivia. Caves are grouped according to closeness, marked with different letters (A: CU1, CU2; B: AS1; C: CY1; D: MS1, PM1, PM2; E: MN1, MN2, MN3; F: MT1; G: TR1, TR2, TR3, TG1, CR1, HJ1, TM1, TM2; see Table 1 for names). 


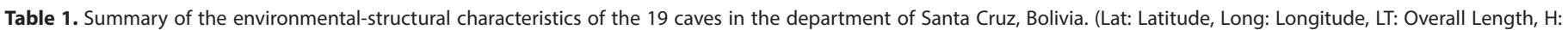
Height, W: Width, Ent: Entrance, RH: Relative humidity, T: Temperature, $\bar{x}$ : Average, SD: Standard Deviation, Max: Maximum, Min: Minimum).

\begin{tabular}{|c|c|c|c|c|c|c|c|c|c|c|c|c|c|c|c|c|c|}
\hline Cave & Month & Lat. & Long. & $\begin{array}{c}\text { LT } \\
\text { (m) }\end{array}$ & $\begin{array}{l}H(m) \\
(\operatorname{Max})\end{array}$ & $\begin{array}{l}\mathbf{H}(\mathrm{m}) \\
(\mathrm{Min})\end{array}$ & $\begin{array}{l}\text { W (m) } \\
(\text { Max) }\end{array}$ & $\begin{array}{l}W(\mathrm{~m}) \\
(\operatorname{Min})\end{array}$ & $\begin{array}{l}N^{\circ} \\
\text { Ent }\end{array}$ & $\begin{array}{c}\text { \%RH } \\
(\bar{x})\end{array}$ & $\begin{array}{c}\% \text { RH } \\
\text { (SD) }\end{array}$ & $\begin{array}{c}\text { \%RH } \\
\text { (Max) }\end{array}$ & $\begin{array}{c}\% \text { RH } \\
\text { (Min) }\end{array}$ & $\begin{array}{c}\mathbf{T}\left({ }^{\circ} \mathbf{C}\right) \\
(\bar{X})\end{array}$ & $\begin{array}{l}\mathrm{T}\left({ }^{\circ} \mathrm{C}\right) \\
(\mathrm{SD})\end{array}$ & $\begin{array}{l}\mathrm{T}\left({ }^{\circ} \mathrm{C}\right) \\
(\operatorname{Max})\end{array}$ & $\begin{array}{l}\mathrm{T}\left({ }^{\circ} \mathrm{C}\right) \\
\text { (Min) }\end{array}$ \\
\hline Curicha (CU1) & June & -16.30397 & -58.30754 & 12.0 & 2.5 & 0.8 & 4.4 & 1.5 & 1 & 68.4 & 1.8 & 70.5 & 64.0 & 26.7 & 0.8 & 27.8 & 26.4 \\
\hline Curicha 2 (CU2) & June & -16.30418 & -58.30721 & 19.0 & 3.1 & 1.8 & 17.9 & 1.9 & 1 & 67.5 & 3.1 & 73.0 & 63.0 & 22.6 & 1.2 & 24.8 & 21.3 \\
\hline Cueva Ascensión (AS1) & June & -16.31121 & -59.44959 & 5.0 & 2.8 & 2.5 & 1.5 & 0.6 & 1 & 71.8 & 5.5 & 79.0 & 66.0 & 24.7 & 2.0 & 26.9 & 21.5 \\
\hline Cueva del Yeso (CY1) & June & -16.35668 & -60.96482 & 18.0 & 6.0 & 1.0 & 17.3 & 3.2 & 1 & 74.8 & 2.7 & 77.0 & 68.0 & 17.5 & 0.4 & 18.0 & 16.3 \\
\hline Miserendino (MS1) & August & -18.36037 & -59.50118 & 208.0 & 40.0 & 1.4 & 7.5 & 0.3 & 3 & 93.8 & 4.8 & 98.0 & 65.0 & 23.9 & 0.9 & 28.5 & 23.0 \\
\hline Puente Mono 1 (PM1) & February & -18.38711 & -59.48085 & 56.0 & 10.0 & 4.5 & 7.5 & 1.5 & 1 & 87.8 & 4.9 & 97.0 & 79.0 & 26.5 & 1.2 & 28.4 & 25.1 \\
\hline Puente Mono 2 (PM2) & February & -18.38944 & -59.48050 & 65.0 & 16.0 & 6.5 & 6.0 & 1.0 & 2 & 86.5 & 3.2 & 94.0 & 83.0 & 26.9 & 0.8 & 27.7 & 24.6 \\
\hline Mono 1 (MN1) & August & -18.26006 & -59.71580 & 13.0 & 1.9 & 1.4 & 12.0 & 2.5 & 2 & 52.5 & 6.7 & 61.0 & 45.0 & 32.2 & 4.3 & 37.1 & 28.0 \\
\hline Mono 2 (MN2) & August & -18.27911 & -59.69929 & 17.0 & 9.5 & 6.0 & 2.5 & 0.4 & 1 & 57.3 & 2.8 & 61.0 & 52.0 & 25.3 & 0.3 & 25.6 & 24.9 \\
\hline Mono 3 (MN3) & August & -18.28369 & -59.69608 & 14.0 & 11.0 & 10.5 & 4.5 & 0.3 & 1 & 53.5 & 1.5 & 56.0 & 52.0 & 26.3 & 0.5 & 26.9 & 25.5 \\
\hline Motacucito (MT1) & February & -19.05967 & -57.91698 & 81.0 & 10.0 & 0.9 & 13.0 & 1.1 & 1 & 93.7 & 5.3 & 99.0 & 79.0 & 29.3 & 1.4 & 36.9 & 27.7 \\
\hline Torres 1 (TR1) & December & -13.66872 & -60.79697 & 40.0 & 10.0 & 0.4 & 6.1 & 0.2 & 1 & 81.0 & 3.9 & 87.0 & 74.0 & 31.0 & 0.2 & 31.0 & 30.4 \\
\hline Torres 2 (TR2) & December & -13.66942 & -60.79706 & 9.0 & 2.7 & 0.5 & 1.2 & 0.5 & 1 & 79.7 & 1.8 & 83.0 & 78.0 & 31.3 & 0.1 & 31.5 & 31.1 \\
\hline Torres 3 (TR3) & December & -13.66984 & -60.79703 & 10.0 & 2.5 & 0.3 & 1.6 & 0.1 & 1 & 66.7 & 6.0 & 77.0 & 60.0 & 31.7 & 0.9 & 33.0 & 30.2 \\
\hline Tigre (TG1) & December & -13.65209 & -60.81296 & 35.0 & 3.5 & 0.4 & 1.7 & 0.2 & 3 & 86.3 & 3.4 & 92.0 & 83.0 & 26.0 & 0.0 & 26.0 & 26.0 \\
\hline La Cruz (CR1) & December & -13.67011 & -60.79615 & 48.0 & 12.0 & 0.5 & 2.0 & 0.3 & 2 & 87.2 & 3.1 & 94.0 & 79.0 & 26.0 & 0.0 & 26.0 & 26.0 \\
\hline Hojarasca (HJ1) & December & -13.66910 & -60.79611 & 17.0 & 12.0 & 0.5 & 2.0 & 0.4 & 1 & 82.4 & 1.4 & 84.0 & 80.0 & 28.4 & 0.2 & 28.7 & 28.1 \\
\hline Torre Mediana (TM1) & December & -13.66678 & -60.79638 & 10.0 & 7.0 & 0.7 & 2.3 & 0.2 & 1 & 77.2 & 1.6 & 81.0 & 75.0 & 30.4 & 0.2 & 30.7 & 30.2 \\
\hline Torre Mediana 2 (TM2) & December & -13.66706 & -60.79678 & 9.0 & 9.0 & 1.0 & 1.0 & 0.4 & 1 & 74.8 & 3.1 & 79.0 & 70.0 & 29.4 & 0.4 & 29.8 & 28.8 \\
\hline
\end{tabular}

To confirm the identity of all bat species, present in each cave, individuals were captured following the methodology by Vargas et al. (2006). Mist nets were placed in narrow areas of the caves to ensure the capture of bats; afterward, these individuals were identified using field keys (Emmons and Feer 1999; Aguirre et al. 2009) and then released.

Relationship between bat abundance and seasonality. To determine if the number of records of bat species in caves is related to the season of the year, a Chi-Square test (Zar 1999) was performed between the number of records of each species in the dry season (April to September) and the rainy season (October to March). The analysis excluded Chrotopterus auritus because of the small number of records for this species.

Interspecific association in caves. The association between the bat species captured in caves was analyzed using presence-absence data to calculate the interspecific association index $V$ for pairs of species (Arita and Vargas 1995). Values for this index range from - 1 (complete segregation), 0 (no association), to 1 (perfect positive association).

Relationship between roost characteristics and bat diversity. To characterize the caves according to the variables evaluated in roosts, a linear correlation analysis (Zar 1999) was conducted between temperature and humidity and structural variables, i.e., cave length (long), number of arms or galleries (passages of varying dimensions), number of entrances (cavities in the ceiling, on the side, or at the bottom of the cave), and structural variation (presence of structures in the roof or walls formed by the dissolution of the parental material, with cracks or cavities), in addition to the biological variables of species richness and diversity.
The complexity parameters of caves were defined based on the presence of galleries, entrances, and variation ( $1=\mathrm{Nil}, 2$ $=$ Medium, 3 = Complex, $4=$ Highly Complex). Accordingly, a cave with a complexity value of 1 has a single gallery, few entries ( $\leq 5)$, and no structural variation; a cave that scored 2 has two galleries, few entries $(>5, \leq 10)$ and little variation in the structure of the roof; a cave that scored 3 has three galleries, entrances $(>10, \leq 20)$ and little variation in the roof and walls; a cave that scored 4 has more than three galleries, entrances ( $>20)$ and a great variation in roof and walls. The relationship of environmental and structural variables with species was explored with a Canonical Correspondence Analysis (CCA), including a permutation test to evaluate the significance of the variables in the analysis (Tel-Braak 1986). The statistical analyses used in the present work were carried out with the program $R$ (v. 3.2.2).

\section{Results}

Seven localities were visited during the study period, finding 19 caves that were georeferenced (Figure 1). Of these, 12 were identified for the first time and named according to their particular characteristics or locations. The mean temperature and humidity, as well as the structural features of each cave, are described in Table 1.

As regards the species composition of roosting bats, we recorded the presence of seven species in three families: Phyllostomidae (4), Natalidae (1), and Emballonuridae (2). The family Phyllostomidae was represented by four subfamilies: Carolliinae, Desmodontinae, Lonchorhininae, and Phyllostominae. The species recorded (ranked from higher to lower frequency of occurrence in caves, in parenthesis) 
were Peropteryx macrotis (12 caves), Carollia perspicillata (7), Desmodus rotundus and Natalus macrourus (3), Peropteryx kappleri (2), and Chrotopterus auritus and Lonchorhina aurita (1; Figure 2).

The observed abundance data are summarized in Table 2, showing that cave MT1 had the highest abundance for three species (C. perspicillata, D. rotundus, and $N$. macrourus). Two individuals of $C$. auritus and eight of L. aurita were found in cave CU1. Caves AS1 and MN1 showed the smallest number of individuals $(n=5)$ in both caves, with a single species ( $P$. macrotis). On the other hand, cave $\mathrm{HJ} 1$ attained the highest number of individuals of $P$. macrotis. It should be mentioned that no individuals were found in cave PM2.

There was a significant relationship between the number of species records in caves and the time of year (Pearson's Chi-square $=72.4 ;$ d.f. $=5 ; P=0.01$ ). In general, we recorded more individuals in caves during the wet season, although the proportions vary according to the species.

As regards interspecific associations in caves, we calculated the $V$ index for all potential pairs of the seven species found in caves, for a total of 21 combinations. This resulted in 12 cases of negative interspecific association; of these, none showed an absolute value of -1 , i.e., the species involved are not completely segregated. There was no case where with $a V$ value of zero (i.e., no association). On the other hand, we found nine cases of a positive association, with a $V$ value of 1 (perfect positive association) only in three cases, namely $L$. aurita-C. perspicillata, L. aurita-C. auritus, and C. auritus-C. perspicillata (Table 3).
Table 2. Total abundance of bat colonies in caves, as calculated by direct daytime observations and photographs. Cper $=C$. perspicillata, Drot $=D$. rotundus, Caur $=C$. auritus, Laur $=$ L. aurita, Nmac $=$ N. macrourus, Pmac $=$ P. macrotis, Pkap $=$ P. kappleri.

\begin{tabular}{|c|c|c|c|c|c|c|c|c|}
\hline Caves & Cpe & Dro & $\mathrm{Cau}$ & Lau & Nma & Pma & Pka & Total \\
\hline Curicha (CU1) & 12 & 5 & 2 & 8 & 0 & 0 & 0 & 27 \\
\hline Curicha 2 (CU2) & 15 & 10 & 0 & 0 & 6 & 0 & 0 & 31 \\
\hline Cueva Ascensión (AS1) & 0 & 0 & 0 & 0 & 0 & 5 & 0 & 5 \\
\hline Cueva del Yeso (CY1) & 15 & 0 & 0 & 0 & 0 & 0 & 0 & 15 \\
\hline Miserendino (MS1) & 0 & 0 & 0 & 0 & 25 & 0 & 0 & 25 \\
\hline Puente Mono 1 (PM1) & 0 & 0 & 0 & 0 & 0 & 8 & 0 & 8 \\
\hline Puente Mono 2 (PM2) & 0 & 0 & 0 & 0 & 0 & 0 & 0 & 0 \\
\hline Mono 1 (MN1) & 0 & 0 & 0 & 0 & 0 & 5 & 0 & 5 \\
\hline Mono 2 (MN2) & 0 & 0 & 0 & 0 & 0 & 8 & 0 & 8 \\
\hline Mono 3 (MN3) & 0 & 0 & 0 & 0 & 0 & 22 & 0 & 22 \\
\hline Motacucito (MT1) & 35 & 50 & 0 & 0 & 10 & 0 & 0 & 95 \\
\hline Torres 1 (TR1) & 10 & 0 & 0 & 0 & 0 & 25 & 0 & 35 \\
\hline Torres 2 (TR2) & 0 & 0 & 0 & 0 & 0 & 10 & 0 & 10 \\
\hline Torres 3 (TR3) & 0 & 0 & 0 & 0 & 0 & 15 & 14 & 29 \\
\hline Tigre (TG1) & 7 & 0 & 0 & 0 & 0 & 4 & 0 & 11 \\
\hline La Cruz (CR1) & 19 & 0 & 0 & 0 & 0 & 0 & 12 & 31 \\
\hline Hojarasca (HJ1) & 0 & 0 & 0 & 0 & 0 & 31 & 0 & 31 \\
\hline Torre Mediana (TM1) & 0 & 0 & 0 & 0 & 0 & 20 & 0 & 20 \\
\hline Torre Mediana 2 (TM2) & 0 & 0 & 0 & 0 & 0 & 11 & 0 & 11 \\
\hline Total & 113 & 65 & 2 & 8 & 41 & 164 & 26 & 419 \\
\hline
\end{tabular}

The assessments of caves revealed that the colonies of $P$. macrotis were compact groups, in contact with each individual, and separated from all other species. We also observed that $D$. rotundus roosts in hard-to-access areas of the cave but can coexist in the proximity of individuals of C. perspicillata, L. aurita, C. auritus, and N. macrourus.

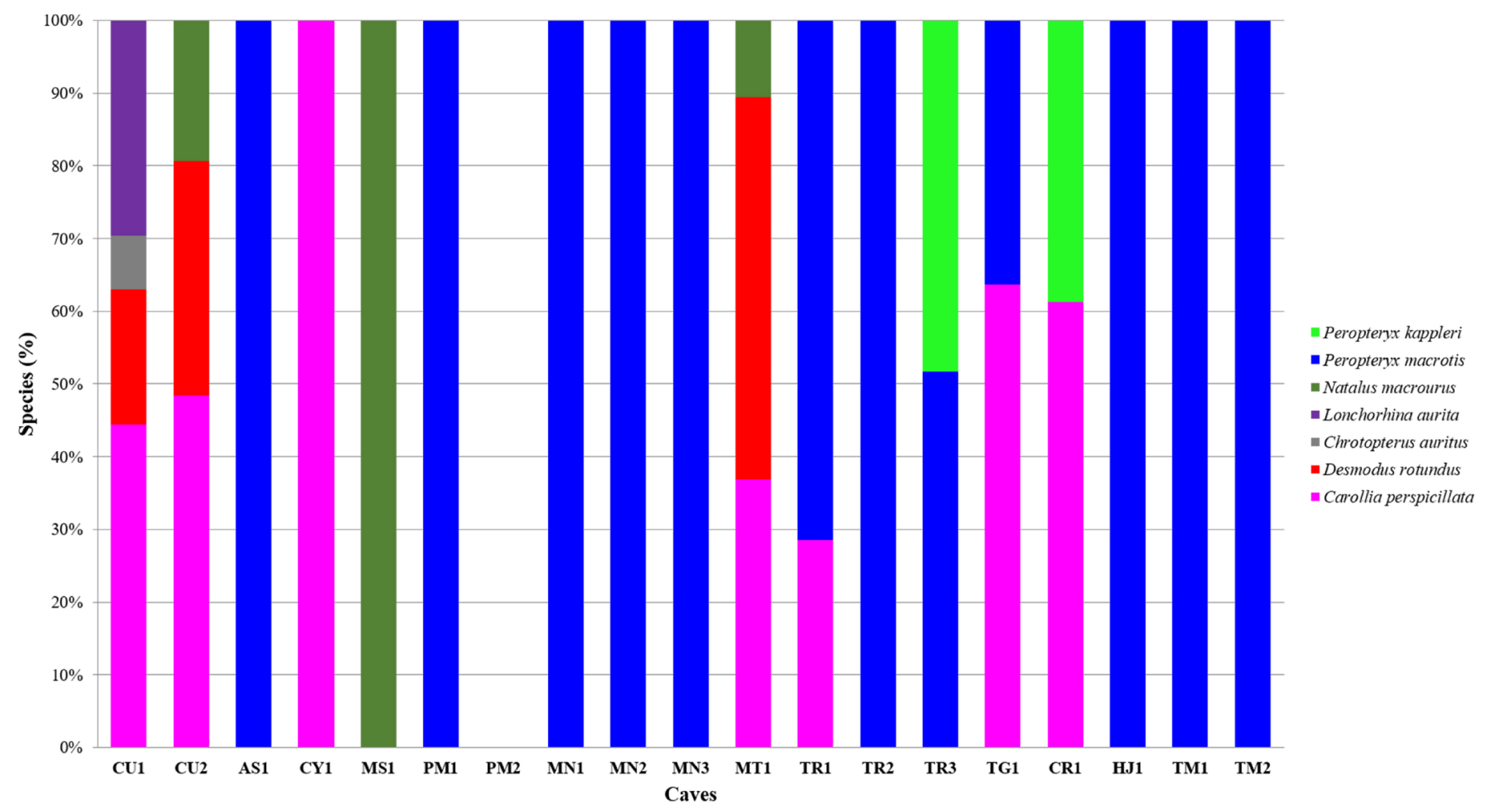

Figure 2. Bat species present in the caves evaluated in the eastern portion of the department of Santa Cruz, Bolivia. Percentages represent the relative abundance of species. 
Table 3. Association index values $(V$ calculated for pairs of species present in the caves of the department of Santa Cruz, Bolivia

\begin{tabular}{lcccccc}
\hline \multicolumn{1}{c}{ Species } & Cpe & Dro & Cau & Lau & Nma & Pma \\
\hline P. kappleri (Pka) & 0.1 & -0.1 & -0.1 & -0.1 & -0.1 & -0.1 \\
P. macrotis (Pma) & -0.5 & -0.6 & -0.3 & -0.3 & -0.6 \\
N. macrourus (Nma) & 0.3 & 0.6 & -0.1 & -0.1 & \\
L. aurita (Lau) & 1.0 & 0.5 & 1.0 & & \\
C. auritus (Cau) & 1.0 & 0.5 & & & \\
D. rotundus (Dro) & 0.6 & & & & \\
C. perspicillata (Cpe) & & & & & \\
\hline
\end{tabular}

The linear correlation analysis (Table 4) shows that long caves are characterized by higher HR; this environmental parameter is related to the structural complexity of the cave. Similarly, caves with a complex structure show a relationship with the number of galleries.

According to the Canonical Correspondence Analysis (Figure 3), the first two axes explain $22 \%$ of the variation in the data. This analysis shows that $C$. perspicillata prefers complex caves with more galleries (MT1 and CR1); $N$. macrourus prefers structurally long caves with high $\mathrm{RH}$ (MS1 and MT1); P. macrotis is found in simple caves that record high temperatures (average $28.6^{\circ} \mathrm{C}$ ); and $D$. rotundus prefers structurally long caves with high $\mathrm{RH}$.

\section{Discussion}

Caves are vital resources allowing the existence of species that are key for ecosystems, such as bats (Altringham 2011). This contrasts with the scarce information on cave bat roosts in Bolivia, given the few studies conducted in this country to date. Thus, to date, only four speleological zones had been recorded for the country: Sorata (La Paz), Carrasco National Park (Cochabamba), Torotoro (Potosí), and Puerto Suárez (Santa Cruz), all including caves that harbor bat species (Aguirre 2007; Miranda-Chumacero 2007). Therefore, the 19 caves identified in the present study are an important contribution to the knowledge of cave roosts in Bolivia, with different species of bats found in $95 \%$ of these shelters.

Regarding the abundance of bats in caves, Arita (1996) mentions that the largest caves shelter the highest numbers of individuals. However, it should be noted that cave size is also related to structural complexity, as larger caves tend to have more chambers, tunnels, and bifurcations. Sherwin et al. (2000) show that simple caves are less populated by bats than those of greater complexity, while Siles et al. (2007) report that caves with high structural complexity tend to shelter a higher abundance of bats than less complex caves of similar size. In our case, cave MT1 follows the same trend: it has the most complex structure, which is probably the reason for the higher abundance of bat species that make good use of the various structural areas to roost.

Some species appear to prefer particular structures in caves. For example, $D$. rotundus roosted in darker and narrower cavities, consistent with the observation reported in this same species by Siles et al. (2007). The use of deeper chambers in caves by compact groups of bats has been reported for Artibeus jamaicensis (Arita and Vargas 1995; Ortega and Arita 1999), C. perspicillata (Trajano and Gimenez 1998; Reis et al. 2007), Phyllostomus hastatus (McCracken and Bradbury 1981), Pteronotus parnellii and Diphylla ecaudata (Arita and Vargas 1995). In the present study, this pattern was observed for C. perspicillata, forming compact groups at the bottom of all caves where it was found. Similarly, our data indicate that $N$. macrourus prefers to roost in caves with very high humidity, since the colonies of this species were always located in narrow passages of low height. This same characteristic was observed by TorresFlores and López-Wilchis (2010) in Natalus stramineus roosting in different caves of Mexico.

One of the major drivers for the presence of bats in caves is microclimate (Kunz 1982), which depends on the length, number of entrances, and depth of the cave, as well as on the temperature and humidity inside it

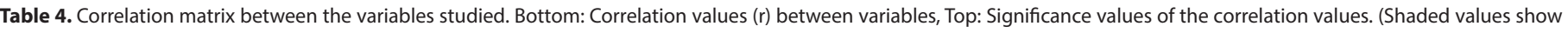
significant correlations at $95 \%$ confidence, $a<0.05$ )

\begin{tabular}{|c|c|c|c|c|c|c|c|c|}
\hline & $\mathbf{R H}$ & Temp. & Lenght & Arms & Entrance & Complexity & Diversity & Richness \\
\hline $\mathbf{R H}$ & & 0.650 & 0.006 & 0.414 & 0.126 & 0.051 & 0.911 & 0.990 \\
\hline Temp. & -0.112 & & 0.398 & 0.790 & 0.576 & 0.921 & 0.990 & 0.962 \\
\hline Lenght & 0.602 & -0.206 & & 0.579 & 0.540 & 0.453 & 0.796 & 0.986 \\
\hline Arms & 0.199 & 0.066 & -0.136 & & 0.014 & 0.001 & 0.607 & 0.473 \\
\hline Entrance & 0.364 & -0.137 & 0.150 & 0.554 & & 0.128 & 0.902 & 0.624 \\
\hline Complexity & 0.454 & -0.024 & 0.183 & 0.715 & 0.362 & & 0.027 & 0.016 \\
\hline Diversity & 0.027 & -0.003 & 0.064 & 0.126 & -0.030 & 0.508 & & 0.000 \\
\hline Richness & -0.003 & -0.012 & 0.004 & 0.175 & -0.120 & 0.546 & 0.957 & \\
\hline
\end{tabular}



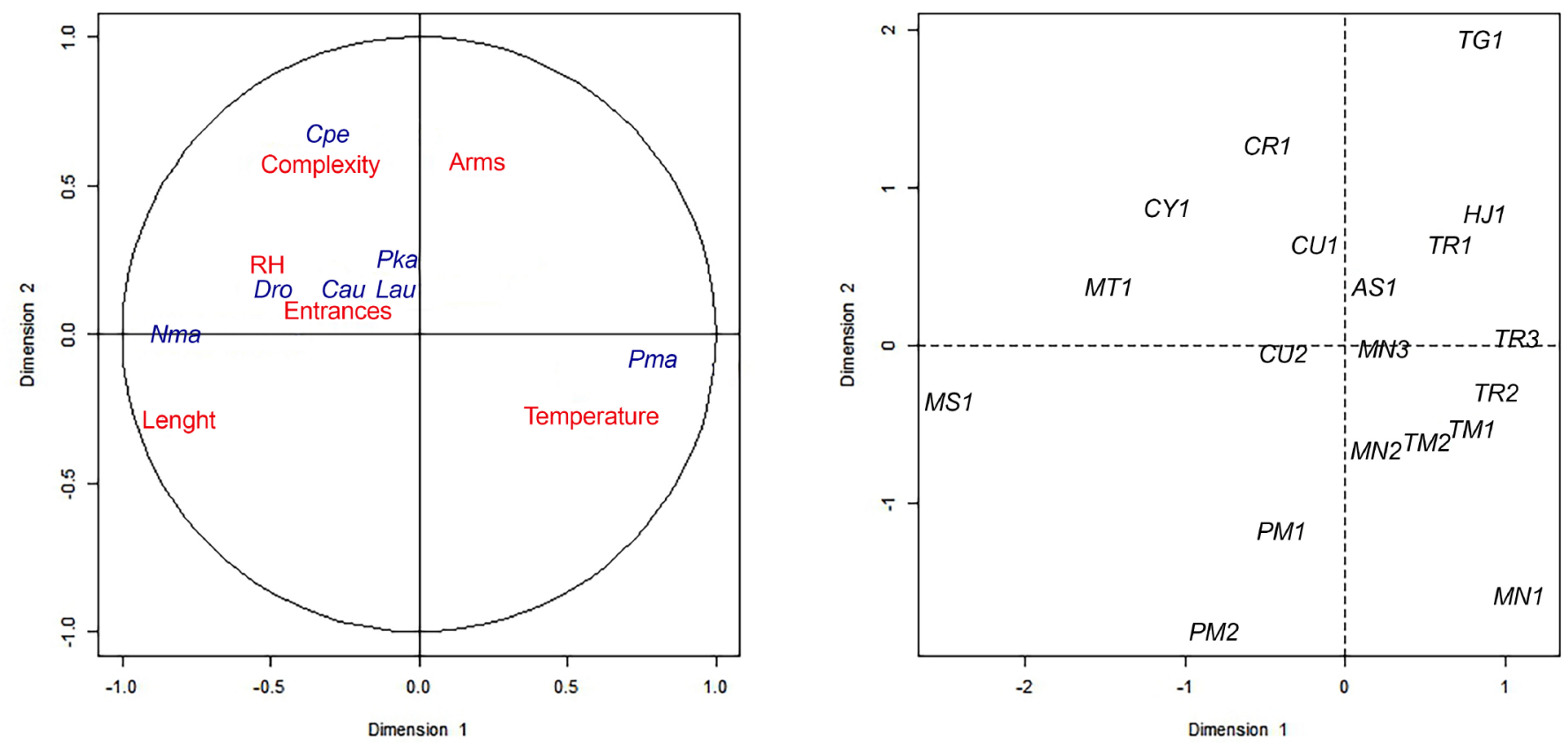

Figure 3. CCA of bat species and environmental-structural characteristics of the caves evaluated. Abbreviations represent each of the caves and bat species evaluated (Cpe: $C$. perspicillata, Dro: D. rotundus, Cau: C. auritus, Lau: L. aurita, Nma: N. macrourus, Pka: P. kappleri, Pma: P. macrotis).

(Siles et al. 2007). The temperature and humidity records showed differences between the 19 caves evaluated. The roosts with the greatest variations in temperature and relative humidity inside caves were MN1, TR3, AS1, MT1, PM1, and MS1 (Table 1), likely as a result of their structural complexity. These features probably provide bats with habitat conditions that best suit their metabolic or energy requirements (Lewis 1995; Sedgeley and O'Donnell 1999). Siles et al. (2007) detected no relationship between temperature and species composition across caves. In the 19 caves explored, bat species probably choose roosting sites based on structural rather than environmental characteristics, although both features (i.e., structure and microclimate) should not be separated, as they are often related (Lewis 1995). Nonetheless, it is challenging to derive generalizations with these data, as temperature was recorded only once in each cave; thus, it should not be used as an indicator of the microclimate inside a cave. Thus, we recommend recording continuous readings over long periods of time (Sherwin et al. 2000). Therefore, continuous monitoring of these caves should be conducted to accurately determine the role of this abiotic factor on the presence and abundance of bats.

On the other hand, the calculated $V$ index values may not show the existence of a particular interspecific interaction, since the fact that two species co-occur in the same roost (cave) does not necessarily imply that both are positively associated. An improved analysis of interspecific associations in caves should consider whether pairs of species occupy the same area within roosting caves. Caves offer a wide variety of sites for bat species to choose from (Hill and Smith 1992; Altringham 1996). Our study evidenced the segregation of some species within their roosts (e. g., $P$. macrotis and P. kappleri), which remain clearly separated from all other bat species in the caves where they were recorded. Therefore, we agree with Swift and Acey (1983), who indicate a nonexistent interspecific interaction when a pair of species occupying the same roosting cave use separate areas within it, leaving and arriving at different times, foraging in different areas, and feeding on different preys. Also, in this study, it was observed that $D$. rotundus shelters in hard-to-access sectors of the cave but might occupy perch sites close to individuals of $C$. perspicillata. These observations are consistent with those reported by Siles et al. (2007), who mention that no interaction between these two species was observed. All our combinations between L. aurita, C. perspicillata, and C. auritus showed a positive association. However, it should be noted that very few individuals were observed or captured; moreover, only these three species co-occur within a single cave. Graham (1988) pointed out that cases where pairs of species roost in the same site are exceptional, being the only ones that clearly showed positive associations between species.

The analysis of the conservation status of bats in Bolivia shows that, of the 138 species present in the country, 12 face some risk level. In the present study, we found L. aurita and $N$. macrourus, which inhabit cave environments only (Lassieur and Wilson 1989; Emmons and Feer 1999) and are categorized as "Endangered" and "Vulnerable", respectively (Vargas and Rocha 2009; Vargas et al. 2009). The records of both species in this study are relevant from a conservation standpoint. L. aurita is a species distributed from Mexico to southeastern Bolivia (Vargas et al. 2009) that may potentially live in mountain ranges in the Chiquitano and Cerrado forest ecoregions and areas adjacent to wetlands (Vargas et al. 2010). To date, the cave reported in San Matías is the only known in Bolivia where this species is present. For N. macrourus, the records confirm its presence in caves MT1 and MS1, as previous reports involving these caves came from personal observations (Aguirre 2007; 
Vargas 2008). Thus, the cave CU2 is a new record of a cave inhabited by this species, considering that only confirmed reports about the distribution of this species in Brazil were available (Delgado-Jaramillo et al. 2018). In this way, caves can constitute important shelters for these species classified as threatened in Bolivia (Aguirre et al. 2010).

Most of the 19 caves evaluated in Santa Cruz represent new records of this type of important environments for bats in Bolivia and thus serve as references for advancing the knowledge about natural history and as key tools for future research on cave ecology.

In this work, we found bat species that could be susceptible to local extinctions, given their highly specialized use of caves. Because of the importance of new bat records in caves, we suggest that the entities involved should manage the conservation of the sites mentioned, in addition to coordinating actions to establish a system of protected areas called Areas or Sites Important for the Conservation of Bats (AICOMs/SICOMs).

This work aims to contribute solid elements to advance the knowledge of cave bat species and their roosting requirements, laying the grounds for future research. Caves are sources of valuable information on population structure, reproduction, behavior, and interspecific association of bat species; in addition, the information in this study contributes to identify shelters requiring conservation measures in our country.

\section{Acknowledgments}

This study was made possible through the logistical and financial support of the Bolivian Bat Conservation Program (PCMB) through Whitley Found for Nature. M. Campero provided valuable suggestions for data analysis. We wish to thank Pamela Carvajal and María Rene Lizarro for their advice on improving the figures. Thanks also to all park rangers and people of the study localities, for their assistance and accompaniment during cave search, making the fieldwork an extraordinary learning experience thanks to their active participation. To S. Solari, Associate Editor, who along with anonymous reviewers, improved this article. Acknowledgments to the Dirección General de Biodiversidad y Áreas Protegidas (DGBAP-MMAyA) for the research licenses to ICA BIOTA (Res. Pref. 293/01; format 1205208). M. E. Sánchez-Salazar translated the manuscript into English. The authors would like to dedicate this article to the memory of Sydney and Justine Anderson. Syd was pivotal in Bolivian mammalogy and crucial to the starting up of bat ecology in the country, setting the basis for ecological as well as taxonomical research. LFA and MIG are particularly grateful for their long term friendship and shared experiences.

\section{Literature cited}

Aguirre, L. F. (ED.). 2007. Historia Natural, Distribución y Conservación de los Murciélagos de Bolivia. Centro de Ecología y Difusión Simón I. Patiño. Santa Cruz, Bolivia.
Aguirre, L. F., A. Vargas, and S. Solari. 2009. Clave de campo para la identificación de los murciélagos de Bolivia. Centro de Estudios en Biología Teórica y Aplicada. Cochabamba, Bolivia.

Aguirre, L. F., M. I. Moya, L. L. Arteaga, M. I. Galarza, A. Vargas, K. Barboza, D. Peñaranda, J. Pérez-Zubieta, M. Terán, and T. TARIFA. 2010. Plan de acción para la conservación de los murciélagos amenazados de Bolivia. BIOTA-PCMB, MMAAVBCC-DGB, UICN-SSC-BSG, CBG-UMSS. Cochabamba, Bolivia.

Aguirre, L. F., F. A. Montaño-Centellas, M. M. Gavilanez, and R. D. Stevens. 2016. Taxonomic and phylogenetic determinants of functional composition of Bolivian bat assemblages. Plos One 11:1-15.

Aguirre, L. F., T. Tarifa, R. B. Wallace, N. Bernal H., L. Siles, E. Aliaga-Rossel, and J. Salazar-Bravo. 2019. Lista actualizada y comentada de los mamíferos de Bolivia. Ecología en Bolivia 54:107-147.

Altringham, J. D. 1996. Bats: Biology and Behavior. Oxford University Press, New York, U.S.A.

Altringham, J. D. 2011. Bats: from Evolution to Conservation. $2^{\text {nd }}$ ed. Oxford University Press. Oxford, U.K.

Anderson, S., K. F. Koopman, and G. K. CReighton. 1982. Bats of Bolivia: an annotated checklist. American Museum Novitates 2750:1-24.

Anderson, S. 1997. Mammals of Bolivia: taxonomy and distribution. Bulletin of the American Museum of Natural History 231:1-652.

ARItA, H. T., AND J. A. Vargas. 1995. Natural history, interspecific association, and incidence of the cave bats of Yucatán, Mexico. The Southwestern Naturalist 40:29-37.

ARITA, H. T. 1996. The conservation of cave-roosting bats in Yucatan, Mexico. Biological Conservation 76:177-185.

Bracamonte, C. 2011. El rol de los murciélagos en el mantenimiento de los bosques. Temas de Biología y Geología del Noa 1:52-57.

Castro-Luna, A., V. J. Sosa, and G. Castillo-Campo. 2007. Quantifying phyllostomid bats at different taxonomic levels as ecological indicators in a disturbed tropical forest. Acta Chiropterologica 9:219-228.

Cleveland, C. J., M. Betke, P. Federico, J. D. Frank, T. G. Hallam, J. Horn, J. D. López JR., G. F. McCracken, R. A. Medellín, A. Moreno-Valdez, C. G. Sansone, J. K. Westbrook, and T. H. Kunz. 2006. Economic value of the pest control service provided by the Brazilian free-tailed bats in south-central Texas. Frontiers in Ecology and the Environment 4:238-243.

Delgado-Jaramillo, M., E. Barbier, andE. Bernard. 2018. New records, potential distribution, and conservation of the Near Threatened cave bat Natalus macrourus in Brazil. Oryx 52:579-586.

Emmons, L., and F. Feer. 1999. Mamíferos de los bosques húmedos de América Tropical. Una guía de campo. Editorial FAN. Santa Cruz, Bolivia.

Galarza, M. I., and L. F. Aguirre. 2007. Conservación de los murciélagos de Bolivia. Pp. 89-135 in Historia Natural, Distribución y Conservación de los Murciélagos de Bolivia (Aguirre, L. F., ed.). Centro de Ecología y Difusión Simón I. Patiño. Santa Cruz, Bolivia.

García-Morales, R., E. Badano, and C. Moreno. 2013. Response of Neotropical bat assemblages to human land use. Conservation Biology 27:1-11. 
Graham, G. L. 1988. Interspecific associations among Peruvian bats at diurnal roosts and roost sites. Journal of Mammalogy 69:711-720.

HiLL, J. E., AND J. D. Smith. 1992. Bats: a natural history. University of Texas Press. Austin, U.S.A.

Hutson, A. M., S. P. Mickleburgh, and P. Racey. 2001. Microchiropteran bats: global status survey and conservation action plan. IUCN/SSC Chiroptera Specialist Group. IUCN, Gland, Switzerland and Cambridge, U.K.

Kunz, T.H. 1982. Roosting ecology. Pp. 1-56 in The ecology of bats (Kunz, T. H., ed.). Plenum Press. New York, U.S.A and London, U.K.

Kunz, T. H., AND M. B. Fenton. 2003. Bat ecology. The University Chicago Press. Chicago, U.S.A.

Kunz, T. H., E. Braun de Torrez, D. Bauer, T. Lobova, and T. H. FLeming. 2011. Ecosystem services provided by bats. Annals of the New York Academy of Sciences 1223:1-38.

LassieuR, S., AND D. E. Wilson. 1989. Lonchorhina aurita. Mammalian Species 347:1-4.

LEwIS, S. E. 1995. Roost fidelity of bats: a review. Journal of Mammalogy 76:418-496.

Lizarro, D., M. I. Galarza, and L. F. Aguirre. 2010. Tráfico y comercio de murciélagos en Bolivia. Revista Boliviana de Ecología y Conservación Ambiental 27:63-75.

McCracken, G. F., and J. W. Bradbury. 1981. Social organization and kinship in the polygynous bat, Phyllostomus hastatus. Behavioral Ecology and Sociobiology 8:11-34.

Medellín, R., M. Equinua, And M. Amin. 2000. Bat diversity and abundance as indicators of disturbance in Neotropical rainforests. Conservation Biology 14:1666-1675.

Miranda-Chumacero, G. 2007. Murciélagos y cavernas en Bolivia. Pp. 57-65 in Historia Natural, Distribución y Conservación de los Murciélagos de Bolivia (Aguirre, L. F., ed.). Centro de Ecología y Difusión Simón I. Patiño. Santa Cruz, Bolivia.

Moya, M. I., M. I. Galarza, A. Vargas, and L. F. Aguirre. 2007. Murciélagos de los Yungas de Bolivia. BIOTA. Cochabamba, Bolivia.

Navarro, G. 2011. Clasificación de la vegetación de Bolivia. Centro de Ecología y Difusión Simón I. Patiño. Santa Cruz, Bolivia.

Ortega, J., AND H. T. ARItA. 1999. Structure and social dynamics of harem groups in Artibeus jamaicensis (Chiroptera: Phyllostomidae). Journal of Mammalogy 80:1173-1185.

PARK, K. J. 2015. Mitigating the impacts of agriculture on biodiversity: bats and their potential role as bioindicators. Mammalian Biology 80:191-204.

Patterson, B. D., M. R. Willig, and R. D. Stevens. 2003. Trophic strategies, niche partitioning, and patterns of ecological organization. Pp. 536-579 in Ecology of bats (Kunz, T. H., and M. B. Fenton, eds.). University of Chicago Press. Chicago, U.S.A.

Reis, N. R., A. L. Peracchi, W. A. Pedro, and I. P. Lima. 2007. Morcegos do Brasil. Londrina, Brasil.

Sedgeley, J. A., AND C. F. J. O'Donnell. 1999. Roost selection by the long-tailed bat, Chalinobolus tuberculatus, in temperate New Zealand rainforest and its implications for the conservation of bats in managed forests. Biology Conservation 88:261-276.

Sherwin, R. E., D. Stricklan, and D. S. Rogers. 2000. Roosting affinities of Townsend's big-eared bat (Corynorhinus townsendii) in northern Utah. Journal of Mammalogy 81:939-947.

Siles, L., A. Muñoz, AND L. F. Aguirre. 2007. Bat diversity in three caves in a montane forest of Bolivia. Ecotropica 13:67-74.
Siles, L., D. M. Brooks, H. Aranibar, T. R. Tarifa, V. M. Julieta, J. M. RoJAS, AND R. J. Baker. 2013. A NEW SPECIES OF MICRONYCTERIS (Chiroptera: Phyllostomidae) from Bolivia. Journal of Mammalogy 94:881-896.

Swift, S. M., AND P. A. Racey. 1983. Resource partitioning in two species of Vespertiolionid bats (Chiroptera) occupying the same roost. Journal of Zoology London 200:249-259.

TARIFA, T. 2014. Historia de la mastozoología en Bolivia. Pp. 69-106 in Historia de la mastozoología en Latinoamérica, las Guayanas y el Caribe (Ortega, J., J. L. Martínez, and D. G. Tirira, eds.). Editorial Murciélago Blanco y Asociación Ecuatoriana de Mastozoología. Quito, Ecuador and Ciudad de México, México.

Tarifa, T., and L. F. Aguirre. 2009. Mamíferos. Pp. 419-572 in Libro rojo de la fauna silvestre de vertebrados de Bolivia (Ministerio de Medio Ambiente y Agua). La Paz, Bolivia.

Tel-BraAk, C. J. F. 1986. Canonical correspondence analysis: a new eigenvector technique for multivariate direct gradient analysis. Ecology 67:1167-1179.

Torres-Flores, J. W., AND R. López-Wilchis. 2010. Condiciones microclimáticas, hábitos de percha y especies asociadas a los refugios de Natalus stramineus en México. Acta Zoológica Mexicana 26:191-213.

Trajano, E., and E. A. Gimenez. 1998. Bat community in cave from eastern Brazil, including a new record of Lionycteris (Phyllostomidae, Glossophaginae). Studies on the Neotropical Fauna and Environment 33:69-75.

Vargas, A., M. I. Galarza, and L. F. Aguirre. 2006. Protocolo para el estudio de comunidades de murciélagos (Phyllostomidae). Pp. 12-22 in Métodos estandarizados para el estudio de murciélagos en Bosques Montanos (Galarza, M. I., and L. F. Aguirre, eds.). BIOTA. Cochabamba, Bolivia.

VarGas, A. 2008. Murciélagos de la Reserva Departamental Valle de Tucavaca. Ed. FCBC. Santa Cruz, Bolivia.

Vargas, A., AND N. Rocha. 2009. Natalus espiritosantensis. Pp. 513-514 in Libro Rojo de la fauna silvestre de vertebrados de Bolivia (Ministerio de Medio Ambiente y Agua, ed.). La Paz, Bolivia.

Vargas, A., K. Barboza, and L. F. Aguirre. 2009. Lonchorhina aurita. Pp. 467-468 in Libro Rojo de la fauna silvestre de vertebrados de Bolivia (Ministerio de Medio Ambiente y Agua, ed.). La Paz, Bolivia.

Vargas, A., L. F. Aguirre, L. Siles, M. Terán, M. I. Moya, and C. M. Zambrana-Torrelo. 2010. Patrones de riqueza potencial de especies y áreas importantes para la conservación de murciélagos (AICOMs) de Bolivia. Revista Boliviana de Ecología y Conservación Ambiental 27:9-24.

Wallace, R. B., H. Gómez, Z. R. Porcel, and D. I. Rumiz (eds.). 2010. Distribución, ecología y conservación de los mamíferos medianos y grandes de Bolivia. Centro de Ecología y Difusión Simón I. Patiño. Santa Cruz, Bolivia.

$Z_{A R}$, J. H. 1999. Bioestatistical analysis. $4^{\text {th }}$ edition. Prentice Hall. Michigan, U.S.A.

Associated editor: Segio Solari

Submitted: May 5, 2020; Reviewed: June 2, 2020;

Accepted: July 14, 2020; Published on line: September 8, 2020. 